\title{
CHARACTERIZATION OF RHIZOBIA AND ARBUSCULAR MYCORRHIZAL FUNGI IN AREAS IMPACTED BY GRAVEL MINING IN BRAZIL ${ }^{1}$
}

\author{
FELIPE FERREIRA DA SILVA, THAINÁ ALVES DOS SANTOS ${ }^{2}$, EDERSON DA CONCEIÇÃO JESUS ${ }^{3}$, \\ GUILHERME MONTANDON CHAER ${ }^{3}$
}

\begin{abstract}
On-shore oil exploration is one of the main economic activities in the semiarid region (Caatinga biome) of the state of Rio Grande do Norte (RN), Brazil. Gravel mining is an activity associated with oil exploration that causes environmental impacts. Gravel is a base-material for constructions, such as roads and pumpjack bases. The areas of gravel mining and other decommissioned areas where the gravel has been deposited must be revegetated with species native to the biome at end of the activity in the site. An efficient strategy for revegetation of degraded areas has been the planting of leguminous species that can associate with rhizobia and arbuscular mycorrhizal fungi (AMF). Nevertheless, the impact of mining activities on the autochthonous populations of these microorganisms is unknown. The objective of the present work is to characterize the density of rhizobia and AMF spores in four areas impacted by the oil exploration in RN when compared to non-impacted adjacent areas. Gravel samples were collected in dry and rainy seasons in two mining areas: one in a pumpjack base, and one in a waste disposal area. Surface soil (topsoil) samples were collected in adjacent areas with native Caatinga vegetation. Assays were carried out to evaluate the most probable number (MPN) of rhizobia and to identify the type and density of arbuscular mycorrhizal fungi (AMF), using rhizobia trap plants Mimosa tenuiflora (Mart.) Benth. and Mimosa caesalpiniifolia Benth. The MPN of rhizobia was low in all areas, but higher in the rainy season. The highest amount and diversity of AMF spores were found in the dry season. Among the symbiotic microorganisms studied, the AMF presented lower densities in the evaluated areas when compared to those in the adjcent native vegetation areas, denoting the impact of this activity.
\end{abstract}

Keywords: Biological nitrogen fixation. Tripartite symbiosis. Recovery of degraded areas. Mining. Oil.

\section{CARACTERIZAÇÃO DE RIZÓBIOS E FUNGOS MICORRÍZICOS ARBUSCULARES EM ÁREAS IMPACTADAS PELA EXPLORAÇÃO DE PIÇARRA NA CAATINGA}

RESUMO - A exploração de petróleo em terra é uma das principais atividades econômicas da região semiárida (Caatinga) do estado do Rio Grande do Norte. Um dos impactos ambientais desta atividade constitui a exploração mineral da piçarra, tipo de cascalho utilizado no embasamento de instalações, como bases de poços, e na construção de estradas de acesso. Ao final da exploração, as jazidas de piçarra e demais áreas descomissionadas, onde a piçarra foi depositada, devem ser revegetadas com espécies nativas do bioma. $\mathrm{O}$ plantio de espécies leguminosas, capazes de realizar associações com rizóbios e fungos micorrízicos arbusculares (FMA), tem se mostrado uma estratégia eficiente para revegetação de áreas degradadas. Entretanto, o impacto das atividades de exploração sobre as populações autóctones desses microrganismos é desconhecido. Esse estudo objetivou caracterizar a densidade de rizóbios e de esporos de FMA em quatro áreas impactadas pela exploração de petróleo no RN em relação ao presente em áreas adjacentes não impactadas. Amostras de piçarra foram coletadas nas estações seca e chuvosa em duas jazidas, uma base de poço e uma central de resíduos. Paralelamente, amostras de solo superficial (topsoil) foram coletadas em áreas adjacentes com vegetação nativa da Caatinga. Ensaios foram conduzidos visando obter o número mais provável (NMP) de rizóbios e a densidade e identificação de fungos micorrízicos arbusculares (FMA). Utilizou-se como plantasisca de rizóbios Mimosa tenuiflora (Mart.) Benth. e Mimosa caesalpiniifolia Benth. O NMP de rizóbios mostrou-se baixo em todas as áreas, sendo superior no período chuvoso. As maiores quantidade e diversidade de esporos de FMA foram obtidas no período seco. Dos microrganismos simbiontes estudados, os FMA apresentaram-se em baixas densidades nas áreas de exploração mineral em relação às de vegetação nativa, refletindo o impacto dessa atividade.

Palavras-chave: Fixação biológica de nitrogênio. Simbiose tripartite. Recuperação de áreas degradadas. Mineração. Petróleo.

\section{${ }^{*}$ Corresponding author}

${ }^{1}$ Received for publication in $11 / 07 / 2018$; accepted in 08/06/2019.

Paper extracted from the masters dissertation of the first author.

${ }^{2}$ Department of Environmental Sciences, Universidade Federal Rural do Rio de Janeiro, Seropédica, RJ, Brazil; felipe.ufrrj@hotmail.com ORCID: 0000-0003-2839-5350, thaina.232@gmail.com-ORCID: 0000-0003-4059-7852.

${ }^{3}$ Laboratory of Forest Leguminous, Empresa Brasileira de Pesquisa Agropecuária, Seropédica, RJ, Brazil; ederson.jesus@embrapa.br ORCID: 0000-0002-2687-8976, guilherme.chaer@embrapa.br - ORCID: 0000-0003-0734-2866. 


\section{INTRODUCTION}

On-shore oil exploration is one of the main economic activities in the semiarid region (Caatinga biome) of the state of Rio Grande do Norte (RN), Brazil. According to the Bulletin of the Oil and Natural Gas Production published by the Brazilian National Petroleum Agency (ANP, 2018), RN has 75 oil and natural gas exploration fields, being the second largest producer of Brazil.

Gravel mining is an activity associated with on-shore oil exploration that causes one of the major environmental impacts. This subsurface material is composed mainly of silt, sand, and saprolite; its is used as filling in ground leveling of sites of oil exploration and production and road construction (CHAER et al., 2011). Gravel mining occurs in fields with areas of 1 to $30 \mathrm{ha}$; it consists of the removal of native vegetation and extraction of the gravel from the subsoil at depths of 3 to $15 \mathrm{~m}$.

After the end of the mining activity, the impacted areas should be revegetated with native species to the biome, which must be able to survive and develop in the substrate of the area. Similarly, decommissioned areas such as pumpjack bases and waste disposal areas, which often received a level of gravel, should be revegetated as defined in a recovery plan for degraded areas previously agreed with the environmental state agency. The revegetation of these areas usually requires the improvement of soil chemical and physical characteristics through fertilizers and mechanical decompaction and trough the selection and introduction of adapted species that can grow and restore the natural succession processes (RESENDE; CHAER 2010).

Studies have shown the successful use of leguminous tree species combined with nitrogenfixing symbiotic bacteria and arbuscular mycorrhizal fungi (AMF) for the recovery of areas degraded by mining activities and recovery of soils with severe erosion (MACEDO et al., 2008; CHAER et al., 2011). Nitrogen-fixing symbiotic bacteria generically termed as rhizobia are recognized for their ability to establish symbiotic relationships with plants of the Leguminosae family by fixing atmospheric nitrogen $\left(\mathrm{N}_{2}\right)$ and supplying nitrogenous compounds to plants in exchange for photoassimilates (DALL'AGNOL et al., 2017). Therefore, the symbiosis with arbuscular mycorrhizal fungi is essential for plant growth by giving the plant access to poorly soluble, lowdiffusion nutrientes, such as phosphorus, through hyphal networks (REINHARDT, 2007; PARNISKE, 2008). Thus, this tripartite symbiosis may favor the establishment and development of plants in areas with physical, chemical, or biological edaphic problems (RODRIGUES et al., 2006; BORGES et al., 2016).

Information about the recovery of areas that had their soil surface soil horizon by mining activities in the Caatinga biome is scarce, and the impact of this activity on rhizobia and AMF populations is poorly known (MERGULHÃO et al., 2010; CAPRONI et al., 2018). The hypothesis of the present study is that areas impacted by gravel exploration or disposal have not enough inoculum of rhizobia and AMF to colonize the introduced native plants. Thus, the objective of this study was to characterize the density of rhizobia and AMF in areas impacted by oil exploration in $\mathrm{RN}$ during the dry and rainy seasons of the year, and to compare the results with those found in non-impacted adjacent areas.

\section{MATERIAL AND METHODS}

\section{Characterization of the study areas}

The study areas consisted of four decommissioned areas degraded by the gravel exploration or disposal: two gravel mines - J1-P $\left(5^{\circ} 24^{\prime} \mathrm{S} ; 36^{\circ} 53^{\prime} \mathrm{W} ;\right.$ Assú, RN) and J2-P (5 ${ }^{\circ} 15^{\prime} \mathrm{S}$; $36^{\circ} 34^{\prime} \mathrm{W}$; Pendências, RN); one pumpjack base (PBP) $\left(5^{\circ} 21^{\prime} \mathrm{S}\right.$; 36 $54^{\circ} \mathrm{O}$; Carnaubais, RN); and one waste disposal area (WDA-P) (524'S; 36 $54^{\circ} \mathrm{O}$; Assú, RN). Areas with native Caatinga vegetation (NV) and adjacents to each degraded area were evaluated, which were named J1-NV, J2-NV, PB-NV, and WDA-NV.

Pumpjack bases are areas with 3,000 to 4,000 $\mathrm{m}^{2}$ leveled with gravel, where oil wells are drilled and the oil pumping structures are installed. Waste disposal areas are those with excavated and impermeabilized tanks used to receive the gravel contaminated with drilling fluids. When these tanks are filled, they receive a 2 to $3 \mathrm{~m}$ layer of gravel for subsequent revegetation. All areas presented this substrate exposed with the absence of vegetation cover, and an incipient expression of natural regeneration when the present study was conducted. The topography of all areas was flat with slopes of up to $1 \%$.

The climate of the region is BSwh', hot and dry, according to the Köppen classification (KÖPPEN, 1948), with a rainy season from January to May, and a dry season from June to December. The average annual temperature is $27.4{ }^{\circ} \mathrm{C}$, and the average annual rainfall is $673 \mathrm{~mm}$, with a dry season of 7 to 8 months (CARMO FILHO; OLIVEIRA, 1995).

\section{Collection and processing of soil and substrate samples}

Three transects of $30 \mathrm{~m}$ were established for the eight studied areas four gravel areas and four adjacent non-impacted areas to representatively cover each area. Six equidistant points throughout 
each transect were established to collect six individual samples of soil or gravel. The individual samples were mixed to form one composite sample per transect, totaling three composite samples per area. The samples were collected from the 0 to 10 $\mathrm{cm}$ and 0 to $20 \mathrm{~cm}$ layers; the latter was used only for the physical and chemical characterization of the soil or gravel. The sampling was performed in November 2016 (dry season) and April 2017 (rainy season).

The collected samples were sieved in a $4 \mathrm{~mm}$ mesh sieve and placed in identified plastic bags.
Samples for microbial quantification were kept refrigerated at $4{ }^{\circ} \mathrm{C}$. All materials used for the collection and processing of the samples were washed in running water and, then, sprayed with $70 \%$ ethanol for disinfection.

\section{Chemical and textural analyses of the samples}

The macronutrient contents, $\mathrm{pH}$, and organic matter in the soil and gravel samples were evaluated by chemical analysis as described by Nogueira and Souza (2005) (Table 1).

Table 1. Chemical attributes of samples from the $0-20 \mathrm{~cm}$ layers of substrate from gravel mines and soil from adjacent areas with native vegetation of the Caatinga biome.

\begin{tabular}{|c|c|c|c|c|c|c|c|c|c|}
\hline \multirow{2}{*}{ Area } & \multirow{2}{*}{ Substrate } & \multirow{2}{*}{$\begin{array}{c}\mathrm{pH} \\
\left(\mathrm{H}_{2} \mathrm{O}\right)\end{array}$} & $\mathrm{P}$ & $\mathrm{K}$ & $\mathrm{Ca}^{2+}$ & $\mathrm{Mg}^{2+}$ & $\mathrm{Al}^{3+}$ & \multirow{2}{*}{$\begin{array}{l}\mathrm{N} \\
\%\end{array}$} & \multirow{2}{*}{$\begin{array}{c}\text { OM } \\
\%\end{array}$} \\
\hline & & & ------ & & ----- & $\mathrm{l}_{\mathrm{c}} \mathrm{dm}$ & ---- & & \\
\hline WDA-P & gravel & 6.95 & 1.86 & 522.54 & 6.03 & 1.53 & 0.00 & 0.03 & 0.20 \\
\hline WDA-NV & soil & 7.78 & 24.46 & 362.57 & 8.23 & 1.07 & 0.00 & 0.17 & 1.73 \\
\hline PB-P & gravel & 4.94 & 2.00 & 44.31 & 0.61 & 0.43 & 0.02 & 0.02 & 0.24 \\
\hline PB-NV & soil & 5.68 & 6.98 & 74.80 & 2.57 & 0.74 & 0.00 & 0.08 & 0.80 \\
\hline J1-P & gravel & 8.10 & 9.58 & 126.12 & 5.52 & 2.41 & 0.00 & 0.01 & 0.20 \\
\hline $\mathrm{J} 1-\mathrm{NV}$ & soil & 7.47 & 26.71 & 236.17 & 9.45 & 1.35 & 0.00 & 0.14 & 1.11 \\
\hline J2-P & gravel & 4.56 & 1.51 & 138.09 & 3.86 & 6.23 & 2.26 & 0.06 & 0.44 \\
\hline $\mathrm{J} 2-\mathrm{NV}$ & soil & 6.77 & 3.68 & 146.84 & 3.41 & 1.08 & 0.00 & 0.10 & 0.86 \\
\hline
\end{tabular}

pH (potentiometry), P (colorimetry), K (flame photometry), Ca and Mg (atomic absorption), Al (titration), and N (Kjedahl), $\mathrm{OM}=$ organic matter.

$\mathrm{WDA}=$ waste disposal area; $\mathrm{PB}=$ pumpjack base; $\mathrm{J} 1=$ mine $1 ; \mathrm{J} 2=$ mine $2 . \mathrm{P}=$ degradaded area with gravel; $\mathrm{NV}=$ adjacent native vegetation area.

The physical characterization of the studied samples consisted of analysis of the sand, silt, and clay percentages and textural classification (CLAESSEN, 1997) (Table 2).

Table 2. Textural classification and percentages of sand, silt, and clay in samples from the $0-20 \mathrm{~cm}$ layers of substrate from gravel mines and soil from adjacent areas with native vegetation of the Caatinga biome.

\begin{tabular}{llcccc}
\hline Area & Substrate & \% Sand & \% Silt & \% Clay & Texture \\
\hline WDA-P & gravel & 55.43 & 20.09 & 24.47 & Loamy \\
WDA-NV & soil & 87.40 & 11.85 & 0.74 & Sandy \\
& & & & & \\
PB-P & gravel & 85.67 & 8.43 & 1.89 & Sandy \\
PB-NV & soil & 91.87 & 6.29 & & Sandy \\
& & & & 7.84 & Sandy \\
J1-P & gravel & 86.00 & 6.15 & 4.82 & Sandy \\
J1-NV & soil & 79.96 & 15.21 & & Loamy \\
& & & & 28.79 & Sandy \\
J2-P & gravel & 53.77 & 17.42 & 7.72 & \\
J2-NV & soil & 82.71 & 9.56 & & \\
\hline
\end{tabular}

$\mathrm{WDA}=$ waste disposal area; $\mathrm{PB}=$ pumpjack base; $\mathrm{J} 1=$ mine $1 ; \mathrm{J} 2=$ mine $2 . \mathrm{P}=$ degradaded area with gravel; $\mathrm{NV}=$ adjacent native vegetation area.

Determination of the most probable number (MPN) of rhizobia

The density of rhizobia in soils and gravel was estimated by the most probable number (NMP) technique (WOOMER, 1994). Leguminous trees were used as trap plants: Mimosa tenuiflora (Mart.) Benth. (jurema-preta) and Mimosa caesalpiniifolia 
Benth. (sabiá), both native to the Caatinga biome. In addition to representing the local flora, these species were chosen because they are among those listed for use in the revegetation of the areas.

Seeds of $M$. tenuiflora and M. caesalpiniifolia were scarified with sulfuric acid $\left(\mathrm{H}_{2} \mathrm{SO}_{4} 98 \%\right)$ for five minutes (ARAÚJO; ANDRADE, 1983) and six min (PASSOS; TAVARES; ALVES, 2007), respectively. Then, their surfaces were disinfected with hydrogen peroxide $\left(30 \% \mathrm{H}_{2} \mathrm{O}_{2}\right)$ for 2 minutes and, subsequently, washed abundantly with sterile water. The seeds were, then, placed in germination plastic boxes $\left(\right.$ Gerbox $\left.^{\circledR}\right)$ previously disinfected with sodium hypochlorite $(0.5 \% \mathrm{NaClO})$, containing autoclaved sand as substrate. These boxes containing sand and seeds were moistened with sterile water and incubated in a germinating chamber at $30^{\circ} \mathrm{C}$.

For supporting and growth of pre-germinated seeds, amber glass bottles were prepared with two absorbent paper filter strips inserted inside them, touching the bottom of the bottle (GUIMARÃES et al., 2012), and $300 \mathrm{ml}$ of nitrogen-free Norris nutrient solution was added to each bottle (GUZMÁN; DOBEREINER, 1968). A small piece of cotton was used to support the pre-germinated seeds in the upper part of the bottles and to favor seedling growth between the two filter paper strips. The bottlenecks were covered with aluminum foil and, then, autoclaved at $121{ }^{\circ} \mathrm{C}$ for 30 minutes.

Ten grams of each gravel or soil sample were suspended in $90 \mathrm{~mL}$ of $0.85 \%$ saline solution. The samples were agitated for 30 minutes in an orbital shaker and, then, serial dilutions up to $10^{-7}$ for soil and up to $10^{-4}$ for gravel samples were made, assuming a lower concentration of cells in these samples in relation to samples from non-impacted areas.

The seedlings were inoculated at 48 hours after their establishment in the greenhouse; $1 \mathrm{~mL}$ aliquots of the seedling dilutions were transferred to their root region (WOOMER, 1994). Dilutions of each material were evaluated in triplicate.

Forty days after the inoculation, the plants were removed from the bottles for the evaluation of nodulation. The MPN (cells $\mathrm{g}^{-1}$ of soil or gravel substrate) and confidence intervals $(p \leq 0.95)$ for the estimates were calculated using the MPN Enumeration System (MPNES 1.0 program) (WOOMER; BENNETT; YOST, 1990). Areas presenting measurements with non-overlaping confidence intervals were considered statistically different.

\section{Recovery and identification of spores of arbuscular mycorrhizal fungi (AMF)}

The AMF spores were recovered from $50 \mathrm{~cm}^{3}$ gravel and soil subsamples of each studied area, using the wet sieving technique (GERDERMANN; NICOLSON, 1963). They were, then, centrifuged in a $50 \%$ sucrose density gradient (JENKINS, 1964), washed four times in sterile distilled water, poured into petri dishes, and counted under a stereoscope for density evaluation (number of spores per $50 \mathrm{~cm}^{3}$ of soil).

Then, the spores obtained were divided into two subsamples arranged in slides, one fixed with polyvinyl alcohol in lactoglycerol (PVLG), and the other fixed with a mixture of PVLG + Melzer Reagent $(1: 1)$. The slides were observed under lightfield illumination and immersion objective optical microscope to identify the AMF species, according to the morphological criteria of Schenck and Perez (1988) and the morphological description available on the International Culture Collection of Arbuscular Mycorrhizal Fungi website (http:// invam.caf.wvu.edu). The taxonomic characteristics observed were: number and type of spore wall layers and their reaction to Melzer reagent, internal wall characteristics (when present), and variation of spore color and size, thus, obtaining the density and richness of AMF species present in the evaluated areas.

\section{RESULTS AND DISCUSSION}

\section{Quantification of rhizobia in the samples}

During the dry season, rhizobia were found only in the $\mathrm{J} 2$ mine (J2-P) area at a density of 21 cells $\mathrm{g}^{-1}$ when using $M$. caesalpiniifolia as a trap plant (Figure 1A); and in J2-P (3 cells g $\left.{ }^{-1}\right), \mathrm{J} 2-\mathrm{NV}$ (3 cells $\left.\mathrm{g}^{-1}\right)$, and $\mathrm{J} 1-\mathrm{NV}$ ( 9 cells $\mathrm{g}^{-1}$ ) areas when using $M$. tenuiflora as a trap plant (Figure 1B). The overlaps of the confidence intervals of their MPN indicated no significant differences between J1-NV, J2-P, and J2-NV (Figure 1B). 
(A)

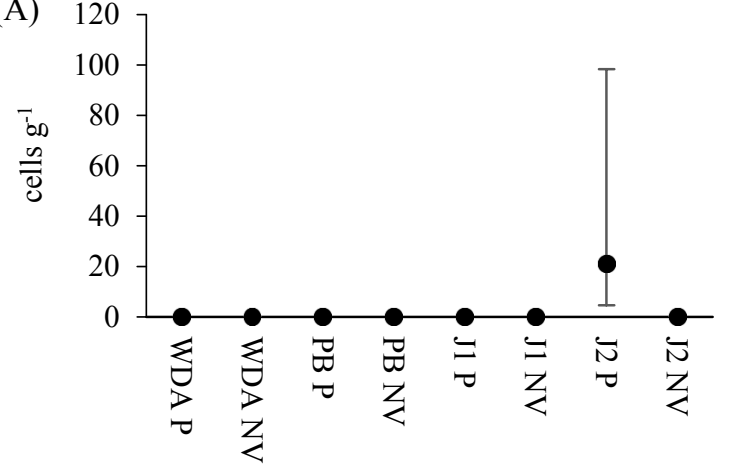

(B)

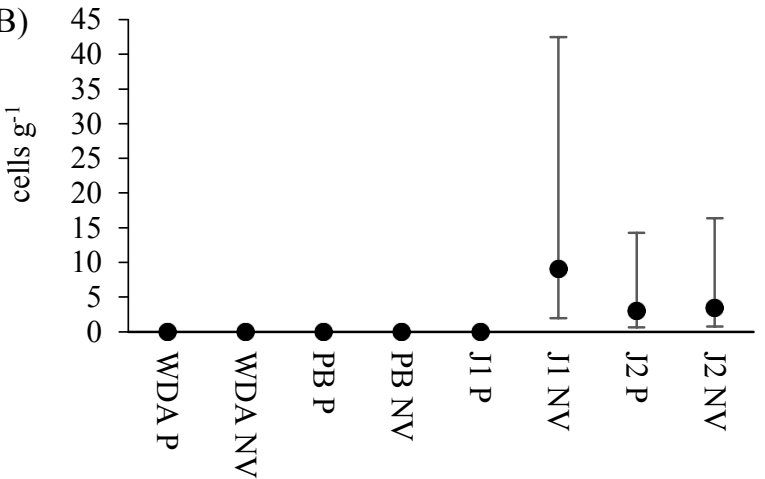

Figure 1. Most probable number of rhizobia (cells $\mathrm{g}^{-1}$ ) in substrate samples from gravel mines and soil from adjacent areas with native vegetation of the Caatinga biome collected in the dry season ( 0 to $10 \mathrm{~cm}$ layer), using Mimosa caesalpiniifolia (A) and Mimosa tenuiflora (B) as trap plants. Bars on the estimates indicate $95 \%$ confidence interval. WDA $=$ waste disposal area; $\mathrm{PB}=$ pumpjack base; $\mathrm{J} 1=$ mine $1 ; \mathrm{J} 2=$ mine $2 . \mathrm{P}=$ degradaded area with gravel; $\mathrm{NV}=$ adjacent native vegetation area.

The rhizobia found in the rainy season had, in general, higher MPN than in the dry season (Figure 2 ), although rhizobia were not found in the WDA$\mathrm{NV}$, PB-NV, and J1-P areas. Rhizobia were found in the WDA-P and PB-P areas only when using $M$.

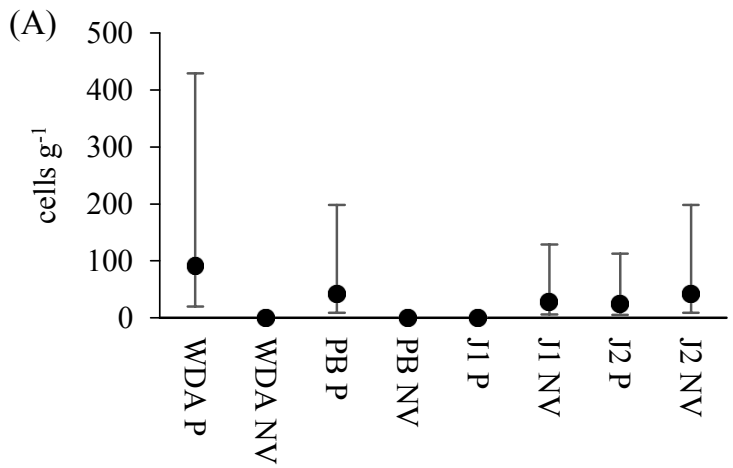

caesalpiniifolia as a trap plant (Figure 2A). The overlaps of the confidence intervals of their MPN indicated no significant differences between WDAP, PB-P, J1-NV, J2-P, and J2-NV areas (Figure 2A and $B)$.

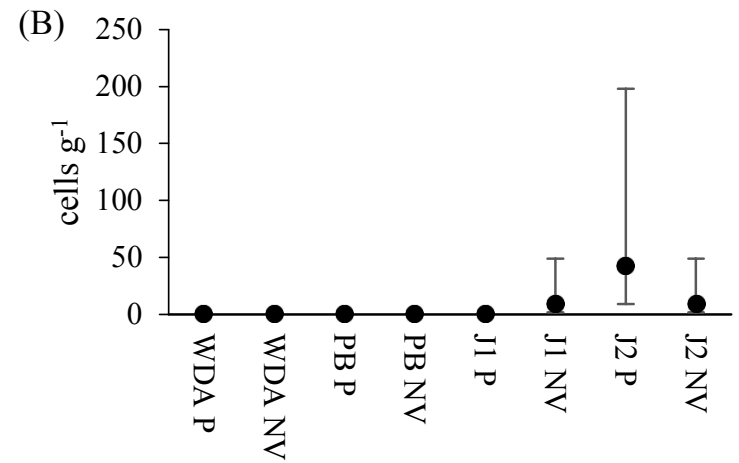

Figure 2. Most probable number of rhizobia (cells $\mathrm{g}^{-1}$ ) in substrate samples from gravel mines and soil from adjacent areas with native vegetation of the Caatinga biome collected in the rainy season (0 to $10 \mathrm{~cm}$ layer), using Mimosa caesalpiniifolia (A) and Mimosa tenuiflora (B) as trap plants. Bars on the estimates indicate $95 \%$ confidence interval. WDA $=$ waste disposal area; $\mathrm{PB}=$ pumpjack base; $\mathrm{J} 1=$ mine $1 ; \mathrm{J} 2=$ mine $2 . \mathrm{P}=$ degradaded area with gravel; $\mathrm{NV}=$ adjacent native vegetation area.

M. caesalpiniifolia presented, in general, higher MPN than M. tenuiflora, indicating a greater affinity of this species to the rhizobia in the evaluated samples. This species can be used as a trap plant because of its high potential for symbiotic association with nitrogen-fixing bacteria (SILVA et al., 2016). When M. tenuiflora was used as a trap plant, only samples from the mine J2-P and adjacent native vegetation areas to $\mathrm{J} 1-\mathrm{P}$ and $\mathrm{J} 2-\mathrm{P}$ mines were counted (Figure 2B).

Although some studies have shown higher quantities of rhizobia in native vegetation areas of the Caatinga biome or fallow areas whem compared to degraded areas (MASCENA, 2014; MERGULHÃO; SILVA; LYRA, 2015), the density of these microorganisms found in the present study was low, regardless of the site or trap plant species used. However, the low MPN found in the dry season, when there was nodulation of trap plants, were similar results to those found by Carreiro et al. (2016) (MPN of 0.55 cells $\mathrm{g}^{-1}$ ) and Souto et al. (2008) (MPN of 1.5 cells $\mathrm{g}^{-1}$ ) in a Caatinga vegetation area, in the same season.

Mascena (2014) evaluated samples collected during the rainy season in the Caatinga biome and found MPN of 13 to 98 cells $\mathrm{g}^{-1}$ in grazing exclusion areas, and 0 to 57 cells $\mathrm{g}^{-1}$ in areas of intensive grazing. Thus, the MPN found by Carreiro et al. (2016) and Souto et al. (2008) for the dry season, and by Mascena (2014) for the rainy season are similar to those found in the present study.

Environmental conditions, such as water deficits, can affect the number of bacteria in the soil; the microbial community is reduced during water deficit periods or in dry regions (COMPANT; VAN DER HEIJIDEN; SESSITSCH, 2010). During the

Rev. Caatinga, Mossoró, v. 32, n. 4, p. 995 - 1004, out. - dez., 2019 
dry season, the intense water deficit may have reduced the soil microbial load, including rhizobium populations, because the lack of moisture reduces soil biomass input and increases the temperature of the surface soil, which is usually exposed to sun radiation.

According to Silva et al. (2017), in addition to rainfall seasonality, other factors may explain the absence of biological nitrogen fixation in nodulating legumes, such as the absence of competitive and efficient native rhizobia under extreme environmental conditions, and the soil available $\mathrm{N}$ to $P$ ratio.

Factors that affect plant development, such as water availability, can affect nodule formation and growth and, consequently, the biological nitrogen fixation (RAMOS et al., 2003). However, information about responses of leguminous plants to environmental variations in terms of symbiotic performance is scarce in the literature, limiting the understanding of various factors that may interfere with the BNF process (RAMOS et al., 2003; SILVA et al., 2016).

The low density of rhizobium populations in the studied areas, including the areas with native vegetation, show the importance of inoculating forest leguminous seedlings that are used for revegetation of areas impacted by the gravel extraction or disposal. This procedure has been efficient for the establishing of these plants in five gravel mines in the state of Rio Grande do Norte (LIMA et al., 2015). The low density of rhizobia found in the soils during the dry season also denoted the importance of selecting strains resistant to long periods of water scarcity and high temperatures, which are characteristics of the Brazilian Semiarid region.

\section{Counting and identification of arbuscular mycorrhizal fungi (AMF)}

The AMF spore densities found were higher in native vegetation areas when compared to the adjacent areas of gravel exploration or disposal, except in the dry season for the J2-P mine (Figure $3 \mathrm{~A}$ and $\mathrm{B})$. The lowest spore density was found in the WDA-P area in the rainy season ( 1 spore per 50 $\mathrm{cm}^{3}$ ), and the highest in the J1-NV area in the dry season ( 73 spores per $50 \mathrm{~cm}^{3}$ ).

(A)

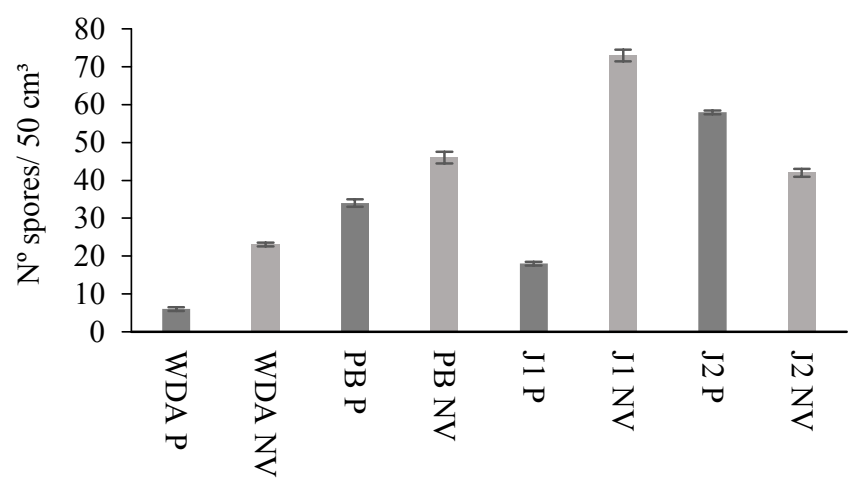

(B)

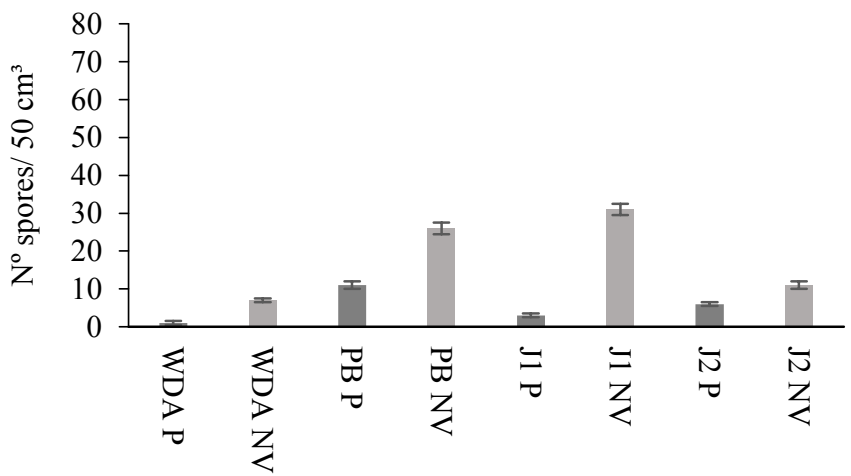

Figure 3. Density of spores of arbuscular mycorrhizal fungi (spores per $50 \mathrm{~cm}^{3}$ ) in substrate samples from gravel mines and soil samples from adjacent areas with native vegetation of the Caatinga biome collected $(0$ to $10 \mathrm{~cm}$ layer $)$ in the dry (A) and rainy (B) seasons. Error bars represent the standard error of the mean. WDA $=$ waste disposal area; $\mathrm{PB}=$ pumpjack base; $\mathrm{J} 1=$ mine $1 ; \mathrm{J} 2=$ mine $2 . \mathrm{P}=$ degradaded area with gravel; $\mathrm{NV}=$ adjacent native vegetation area. 
Studies have shown reduction or elimination of AMF in areas due to soil surface removal or mineral extraction (ALLEN, 1991; SILVA et al., 2001; RODRIGUES et al., 2006). Several alternatives can be employed to restore the AMF inoculum potential in areas where these microorganisms have been suppressed by mining activities, such as the use of seedlings inoculated with AMF or the deposition of surface soil from areas recently opened for exploration into recovering areas (CAPRONI et al., 2005; CARNEIRO et al., 2012; TEIXEIRA et al., 2017).

In addition to the removal of soil surface layers by mineral extraction, the amount of $\mathrm{AMF}$ spores can be influenced by factors inherent to the host plant phenology and the characteristic rainfall irregularity of arid and semiarid environments (MOHAMMAD; HAMAD; MALKAWI, 2003).

The number of spores decreased significantly from the dry to the rainy season (Figure $3 \mathrm{~A}$ and $\mathrm{B}$ ). The higher AMF spore density found in the dry season may be related to the sporulation induction by water stress periods and to the favored conditions for their germination in rainy seasons (CAPRONI et al., 2003; SOUZA et al., 2003; FERREIRA, 2010).

The spore richness analysis showed presence of six AMF species in the evaluated areas, including representatives of the genera Glomus, Rhizophagus, Gigaspora, and Ambispora (Table 3). The highest richness was found in the dry season, which is related to the higher quantity of spores obtained in collections at this season. The species found in the rainy season were Glomus macrocarpum, Rhizophagus clarus, and Gigaspora sp.; and in the dry season, the species Ambispora leptoticha, Glomus clavisporum, and Glomus tortuosum were added to those.

Table 3. Species of arbuscular mycorrhizal fungi found in substrate and soil samples collected in the dry and rainy seasons in areas of gravel exploration and disposal and in adjacent native vegetation areas in the state of Rio Grande do Norte, Brazil.

\begin{tabular}{|c|c|c|c|}
\hline Area & Material & $\begin{array}{c}\begin{array}{c}\text { Species of AMF } \\
\text { (dry season) }\end{array} \\
\end{array}$ & $\begin{array}{l}\text { Species of AMF } \\
\text { (rainy season) }\end{array}$ \\
\hline WDA-P & gravel & Rhizophagus clarus; Glomus macrocarpum & G. macrocarpum \\
\hline WDA-NV & soil & G. macrocarpum; Glomus tortuosum & G. macrocarpum \\
\hline PB-P & gravel & G. macrocarpum & R. clarus; G. macrocarpum \\
\hline PB-NV & soil & Gigaspora sp.; Glomus clavisporum & G. macrocarpum; Gigaspora sp. \\
\hline $\mathrm{J} 1-\mathrm{P}$ & gravel & R. clarus & G. macrocarpum \\
\hline $\mathrm{J} 1-\mathrm{NV}$ & soil & G. macrocarpum; Ambispora leptoticha & G. macrocarpum; Gigaspora sp. \\
\hline J2-P & gravel & R. clarus; G. macrocarpum & G. macrocarpum \\
\hline $\mathrm{J} 2-\mathrm{NV}$ & soil & R. clarus; G. macrocarpum & R. clarus; G. macrocarpum \\
\hline
\end{tabular}

$\mathrm{WDA}=$ waste disposal area; $\mathrm{PB}=$ pumpjack base; $\mathrm{J} 1=$ mine $1 ; \mathrm{J} 2=$ mine $2 . \mathrm{P}=$ degradaded area with gravel; $\mathrm{NV}=$ adjacent native vegetation area (Caatinga biome).

The occurrence of the largest number of species belonging to Glomus (including Rhizophagus clarus, formerly called Glomus clarum) corroborates the results of other studies carried out in semiarid regions (CAPRONI et al., 2003; SOUZA et al., 2003; SILVA et al., 2005; LIMA; SALCEDO; FRAGA, 2007). According to Maia, Yano-Melo and Goto (2006), the predominance of the Glomus genus over other species in semiarid regions is common, since it is one of the genera with the largest number of described species.

Ferreira (2010) studied the ecology and diversity of AMF in the Caatinga biome and found greater diversity of AMF spores during the dry season, reporting species of several genera, including Gigaspora and Glomus; their results showed that, despite the environmental conditions of Caatinga (water deficit and high soil salinity), this biome has high AMF diversity and, possibly, a large number of new species to be discovered.

\section{CONCLUSIONS}

Areas of gravel exploration and disposal and their adjacent areas with native vegetation present low populations of rhizobia capable of nodulating Mimosa caesalpiniifolia and M. tenuiflora.

There is a higher density of arbuscular mycorrhizal fungi propagules in native vegetation areas than in areas degraded by the exploration or disposal of gravel.

The dry season in the Caatinga biome tends to reduce the density of soil rhizobia in the evaluated areas, but induces the formation of spores of arbuscular mycorrhizal fungi.

The main genera of arbuscular mycorrhizal fungi found in the evaluated areas were Glomus and Rhizophagus. 


\section{ACKNOWLEDGMENTS}

The authors thank the Brazilian Coordination for the Improvement of Higher Education Personnel (CAPES) for granting a master's scholarship to the first author. This research was financed by the Cooperation Agreement $n^{\circ}$. 0050.0098775.15.9 between the Petróleo Brasileiro S.A. (Petrobras), Brazilian Agricultural Research Corporation (Embrapa), and Research and Development Support Foundation (FAPED).

\section{REFERENCES}

AGÊNCIA NACIONAL DO PETRÓLEO - ANP. Boletim da Produção de Petróleo e Gás Natural. Disponível em: <http://www.anp.gov.br/? $\mathrm{dw}=74333>$. Acesso em: 15 fev. 2018.

ALLEN, M. F. The ecology of mycorrhizae. San Diego: Cambridge University Press, 1991. 200 p.

ARAÚJO, M. S.; ANDRADE, G. C. Métodos para superar a dormência tegumentar em sementes de jurema-preta (Mimosa hostilis Benth.). Boletim de Pesquisa Florestal, n. 6/7, p. 26-32, jun./dez. 1983.

ARAÚJO, M. S.; ANDRADE, G. C. Métodos para superar a dormência tegumentar em sementes de jurema-preta (Mimosa hostilis Benth.). Boletim de Pesquisa Florestal, Colombo, n. 6/7, p. 26-32, 1983.

BORGES, W. L. et al. Rhizobial characterization in revegetated areas after bauxite mining. Brazilian Journal of Microbiology, v. 47, n. 2, p. 314-321, 2016.

CAPRONI, A. L. et al. Ocorrência de fungos micorrízicos arbusculares em áreas revegetadas após mineração de bauxita em Porto Trombetas, Pará. Pesquisa Agropecuária Brasileira, v. 38, n. 12, p. 1409-1418, 2003.

CAPRONI, A. L. et al. Fungos micorrízicos arbusculares em estéril revegetado com Acacia mangium, após mineração de bauxita. Revista Árvore, v. 29, n. 3, p. 373-381, 2005.

CAPRONI, A. L. et al. Diversity of Arbuscular Mycorrhizal Fungi in an Amazon Environment after Mining. Floresta e Ambiente, v. 25, n. 3, p. 1-9, 2018.

CARMO FILHO, F.; OLIVEIRA, O. F. Mossoró: Um município do semi-árido nordestino, caracterização climática e aspecto florístico. Mossoró, RN: ESAM, 1995. 62 p. (Coleção mossoroense, série B).
CARNEIRO, R. F. V. et al. Fungos micorrízicos arbusculares como indicadores da recuperação de áreas degradadas no Nordeste do Brasil. Revista Ciência Agronômica, v. 3, n. 4, p. 648-657, 2012.

CARREIRO, D. A. et al. Microrganismos indicadores de qualidade do solo de áreas produtoras de coco no perímetro irrigado de São Gonçalo-PB. In: CONGRESSO INTERNACIONAL DA DIVERSIDADE DO SEMIÁRIDO, 2., 2016, Campina Grande. Anais... Campina Grande: CONIDIS, 2016

CHAER, G. M. et al. Nitrogen-fixing legume tree species for the reclamation of severely degraded lands in Brazil. Tree Physiology, v. 31, n. 2, p. 139149, 2011.

COMPANT, S.; VAN DER HEIJIDEN, M. G. A.; SESSITSCH, A. Climate change effects on beneficial plant-microorganism interaction. Microbiology Ecology, v. 73, n. 2, p. 197-214, 2010.

CLAESSEN, M. E. C. (Org.). Manual de métodos de análise de solo. 2. ed. Rio de Janeiro, RJ: Embrapa-CNPS,1997. 212 p. (Embrapa-CNPS. Documentos, 1).

DALL'AGNOL, R. F. et al. Genetic diversity of symbiotic Paraburkholderia species isolated from nodules of Mimosa pudica (L.) and Phaseolus vulgaris (L.) grown in soils of the Brazilian Atlantic Forest (Mata Atlântica). FEMS Microbiology Ecology, v. 93, n. 4, p. fix027, 2017.

FERREIRA, A. C. A. Ecologia e diversidade de fungos micorrízicos arbusculares em área de Caatinga. 2010. 88 f. Dissertação (Mestrado em Biologia de Fungos: Área de Concentração em Micologia Básica) - Universidade Federal de Pernambuco, Recife, 2010.

GERDERMANN, J. N.; NICOLSON, T. H. Spores of mycorrhizal Endogone species extracted from soil by wet sieving and decanting. Transactions of the British Mycological Society, v. 46, n. 2, p. 235-244, 1963.

GUZMÁN, I.; DOBEREINER, J. Effectiveness and efficiency in the symbiosis of four cross-inoculated tropical legumes. In: REUNIÃO LATINO AMERICANA SOBRE INOCULANTES PARA LEGUMINOSAS, 4., 1968, Porto Alegre. Anais... Porto Alegre: Universidade Federal do Rio Grande do Sul, 1968. p. 81-91.

GUIMARÃES, A. A. et al. Genetic and Symbiotic Diversity of Nitrogen-Fixing Bacteria Isolated from Agricultural Soils in the Western Amazon by Using 
Cowpea as the Trap Plant. Applied and Environmental Microbiology, v. 78, n. 18, p. 67266733, 2012.

JENKINS, W. R. A rapid centrifugal floatation technique for separating nematodes from soil. Plant Disease Report, v. 48, n. 8, p. 692-694, 1964.

KÖPPEN, W. Climatología: con un estudio de los climas de la Tierra. Ciudad del Méjico: Fondo de Cultura Económica, 1948. 478 p.

LIMA, R. L. F. A.; SALCEDO, I. H.; FRAGA, V. S. Propágulos de fungos micorrízicos arbusculares em solos deficientes em fósforo sob diferentes usos, da região semi-arida no nordeste do Brasil. Revista Brasileira de Ciência do Solo, v. 31, n. 2, p. 257 268, 2007.

LIMA, K. D. R. et al. Seleção de espécies arbóreas para revegetação de áreas degradadas por mineração de piçarra na Caatinga. Revista Caatinga, v. 28, n. 1, p. 203-213, 2015.

MACEDO, M. O. et al. Changes in soil $\mathrm{C}$ and $\mathrm{N}$ stocks and nutrient dynamics 13 years after recovery of degraded land using leguminous nitrogen-fixing trees. Forest Ecology and Management, v. 255, n. 5, p. 1516-1524, 2008.

MAIA, L. C.; YANO-MELO A.M.; GOTO, B. T. Filo Glomeromycota. In: GUSMÃ̃O, L. F. P., MAIA, L. C. (Eds.). Diversidade e caracterização dos fungos do semi-árido. Pernambuco: Associação Plantas do Nordeste - APNE e MCT, 2006. v. 2, cap. 6, p. 109-126.

MASCENA, A. M. Diagnóstico da ocorrência de micro-organismos simbiontes em áreas sob processo de desertificação no município de Irauçuba, Ceará. 2014. 85 f. Tese (Doutorado em Solos e Nutrição de Plantas: Área de Concentração em Microbiologia do Solo) - Universidade Federal do Ceará, Fortaleza, 2014.

MERGULHÃO, A. C. E. S et al. Diversity of arbuscular mycorrhizal fungi in a gypsum mining impacted semiarid area. Acta Botanica Brasilica, v. 24, n. 4, p. 1052-1061, 2010.

MERGULHÃO, A. C. E. S.; SILVA, M. L. R. B.; LYRA, M. C. C. P. Avaliação do estado microbiológico do solo em área preservada $\mathrm{e}$ impactada por mineração no semiárido de Pernambuco. In: CONGRESSO BRASILEIRO DE CIÊNCIA DO SOLO, 35., 2015, Natal. Anais... Natal: Sociedade Brasileira de Ciência do Solo, 2015. v. 1299, p. 1-5.

MOHAMMAD, M. J.; HAMAD, S. R.; MALKAWI,
H. I. Population of arbuscular mycorrhizal fungi in semiarid environment of Jordan as influenced by biotic and abiotic factors. Journal of Arid Environments, v. 53, n. 3, p. 409-417, 2003.

NOGUEIRA, A. R. A.; SOUZA, G. B. Manual de laboratórios: solo, água, nutrição vegetal, nutrição animal e alimentos. São Carlos, SP: Embrapa Pecuária Sudeste, 2005. 334 p.

PARNISKE, M. Arbuscular mycorrhiza: the mother of plant root endosymbioses. Nature Reviews Microbiology, v. 6, n. 10, p. 763-775, 2008.

PASSOS, M. A.; TAVARES, K. M. P.; ALVES, A. R. Germinação de sementes de sabiá (Mimosa caesalpiniifolia Benth.). Revista Brasileira de Ciências Agrárias, v. 2, n. 1, p. 51-56, 2007.

RAMOS, M. L. G. et al. Effect of water stress on nitrogen fixation and nodule structure of common bean. Pesquisa Agropecuária Brasileira, v. 38, n. 3, p. 339-347, 2003.

REINHARDT, D. Programming good relations development of the arbuscular mycorrhizal symbiosis. Plant Biology, v. 10, n. 1, p. 98-105, 2007.

RESENDE, A. S.; CHAER, G. M. Manual para recuperação de áreas degradadas por extração de piçarra na Caatinga. Seropédica, RJ: Embrapa Agrobiologia, 2010. 78 p.

RODRIGUES, L. A. et al. Revegetação de áreas degradadas pela extração de argila no Norte do estado do Rio de Janeiro. Revista Perspectivas, v. 5, n. 10, p. 88-105, 2006.

SCHENCK, N. C.; PEREZ, Y. A manual for identification of vesicular-arbuscular mycorrhizal fungi. 2 ed. Gainesville: University of Florida, 1988. 241 p.

SILVA, G. A. et al. Potencial de infectividade de fungos micorrízicos arbusculares oriundos de área de caatinga nativa e degradada por mineração, no Estado da Bahia, Brasil. Revista Brasileira de Botânica, v. 24, n. 2, p. 135-143, 2001.

SILVA, G. A. et al. Arbuscular mycorrhizal fungi in a semiarid copper mining area in Brazil. Mycorrhiza, v. 15, n. 1, p. 47-53, 2005.

SILVA, V. S. G. et al. Systems of land use affecting nodulation and growth of tree legumes in different soils of the Brazilian semiarid area. African Journal of Agricultural Research, v. 11, n. 40, p. 3966-3974, 2016 
SILVA, A. F. et al. Biological nitrogen fixation in tropical dry forests with different legume diversity and abundance. Nutrient Cycling in Agroecosystems, v. 107, n. 3, p. 321-334, 2017.

SOUTO, P. C. et al. Comunidade microbiana e mesofauna edáficas em solo sob Caatinga no semiárido da Paraíba. Revista Brasileira de Ciência do Solo, v. 32, n. 1, p. 151-160, 2008.

SOUZA, R. G. et al. Diversidade e potencial de infectividade de fungos micorrízicos arbusculares em área de Caatinga, na Região de Xingó, Estado de Alagoas, Brasil. Revista Brasileira de Botânica, v. 26, n. 1, p. 49-60, 2003.

TEIXEIRA, A. F .S. et al. Arbuscular mycorrhizal fungal communities in an iron mining area and its surroundings: Inoculum potential, density, and diversity of spores related to soil properties. Ciência e Agrotecnologia, v. 41, n. 5, p. 511-525, 2017.

WOOMER, P. L.; BENNETT, J.; YOST, Y. Overcoming the inflexibility of most probable number procedures. Agronomy Journal, v. 82, n. 2, p. 349-353, 1990.

WOOMER, P. L. Most Probable Number Counts. In: WEAVER, R.W. et al. Methods of soil analysis. Part 2. Microbiological and biochemical properties. Madison: Soil Science Society of America, 1994. 1692 p. 